\title{
Automated Greenhouses for the Reduction of the Cost of the Family Basket in the District of Villa El Salvador-Perú
}

\author{
Pedro Romero Huaroto ${ }^{1}$, Abraham Casanova Robles ${ }^{2}$, Nicolh Antony Ciriaco Susanibar ${ }^{3}$, Avid Roman-Gonzalez ${ }^{4}$ \\ Electronics and Telecommunication Department ${ }^{1,2,3}$ \\ Aerospace Sciences and Health Research Laboratory (INCAS- Lab) ${ }^{4}$ \\ Universidad Nacional Tecnológica de Lima Sur, Lima, Peru ${ }^{1,2,3,4}$
}

\begin{abstract}
Today, the cost of the family basket is gradually increasing, not only globally but also in our country. This increase includes the demand for vegetables and fresh vegetables that allow people to improve their quality of life. Also, this consists of the search for a healthier and more natural diet with the help of existing technologies. Against this, we propose the implementation of an automated greenhouse, with sensors and actuators that allow controlling a microclimate for correct and efficient development of vegetables. With this proposal, we obtain a saving of $50 \%$ equivalent to 8.00 dollars, concerning the planting of lettuce against market prices, thus achieving a reduction in the family basket.
\end{abstract}

Keywords-Germination; protocol i2c; hummus; atmega

\section{INTRODUCTION}

The automated greenhouses are gaining rapid reception, thanks to this; it is possible to plant non-native plants within these environments. Nowadays, the tremendous technological advance makes possible the recreation or artificial implementation of natural habitats and processes. This situation has, as a consequence, a benefit and a higher yield of the products that are elaborated in the said process [1].

At present, the creation of greenhouses for the development and growth of plants or vegetables favors different ecosystems and reuse of it [2]. Several studies indicate that the production of plants in these protected and isolated structures have higher growth and creation that is reflected in the energy, water, and economic savings where one aims [3]. As they adapt to the necessary conditions of climate change, which leads to optimizing the conditions of crop growth. Management is improved at the time of providing efficient irrigation and increases efficiency in production [4].

According to the National Institute of Statistics and Informatics of Peru (INEI), one knows that the cost of the family basket is gradually increasing. In 2015 to 2016, the increase was $0.041 \%$, and from 2017 to 2018 , the increase was drastic at $0.93 \%$ affects families in our country [5].

Faced with this problematic situation, the objective of this work is to implement an automated greenhouse. This greenhouse works automatically and generates decisions by executing corrective actions, to adjust the climatic parameters of the variables such as temperature, humidity, and humidity of the land.
The importance of our idea is to reduce the cost of the family basket and improve people life quality. Also, the use of recycling in the implementation process is to take care of the environment and minimize the costs of assembling the automated greenhouse. Likewise, one focuses on the goal of self-sustainable development for the benefit of families in Villa El Salvador.

The idea is to give a second option to people who are in a situation of poverty. The idea is that people can have the capacity to generate their essential consumption foods and in a sustained manner over time, with a minimum of investment. We will take advantage in a specific part of the eco-friendly means of the District Villa el Salvador, like the humidity that oscillates between $80 \%$ to $90 \%$, that is very favorable for the sowing of certain products [6].

There are several studies regarding the reduction of the family basket; one shows the following antecedents to have a current vision of this problem.

In [7] the authors corroborate the importance of automated greenhouses in the study of pathogens or diseases, which could affect the growth of the tomato crop in the process of its development. Likewise, they are stimulated with different climatic changes to see the diversity of diseases that affect tomato.

The author in [8] proposes a technological alternative that helps to mitigate the problem of the cost of the family basket through a start-up aimed at municipalities. Likewise, the creation of the CanastAPP is a web platform where the products of first need at a lower market cost.

In [9], the author makes a situational diagnosis, with the purpose of particular the poorest neighborhoods of its community. This diagnosis is focused on organic urban agriculture, to obtain a well to be with natural products and to reduce the expenses in the purchases of the familiar basket. Likewise, it conducts market studies to determine the demand for organic products, and quantify said demand to show these products in urban agriculture.

In [10], the Peruvian state carries out social programs to support the economy and the family basket. These are the milk glass program, the complementary feeding program-PCA, national program, direct support to the poorest and national 
plan of school feeding Qali Warma. All these programs are state initiatives, support people who have fewer resources and improve their quality of life.

In [11], the authors are looking to improve the quality and productivity of lettuce consumption in the national market, through a large-scale hydroponic greenhouse. Due to the current deficiency in vegetable growers, this research is motivated to offer a quality product and think about the final consumer.

In [12], it is proposed to improve the production of vegetables in high Andean areas in Cusco - Peru to 3330 masl. Through an automated greenhouse prototype taking advantage of the materials of the city for the construction of the same, obtaining a significant saving of 10 dollars per square meters.

This work continues as follows: Section II shows the methodology that is developed to reduce the cost of the family basket in the Villa El Salvador District. In Section III, the authors present the results obtained. Finally, in Section IV, one can see the discussion and conclusion.

\section{MethodOLOGY}

\section{A. Implementation of the Automated Greenhouse}

For the construction and implementation of the computerized greenhouse, one searched for a relatively small area to perform the tests with dimensions of 2 meters long by 1.2 meters wide. The implementation is followed by plastic supports to make the structure for the aspects of the greenhouse. Then, proceeded to make the electrical wiring for the power supply of the sensors and actuators, so that they can be connected to the analog reading pins using cable UTP category 5 of 8 threads. The DTH 11, MQ2 sensors and humidity sensor were placed strategically in the greenhouse, to obtain better readings. Likewise, the LCD screen with the I2C adapter was placed in the front, so that anyone can see the realtime data of the variables counted. The analog reading terminals are redirected to a point in common so that it reaches the central controller, which is the Arduino mega 2560. One uses the relay module for the actuators to separate the different suppliers to create a stable system. In Fig. 1, one can appreciate the flow of implementation and results.

Finally, one closes the greenhouse hermetically with transparent plastic. The idea is to let's pass the solar brightness and this way to realize the proper growth. One can see in Fig. 2 the scheme of implementation.

It also has to get adequate land for planting that meets high standards of nutrients. To obtain a product of better quality and at a low cost, this land must be fertilized with hummus and fertilizers, which help the growth of the ideally. It also seeks proper oxygenation to meet the essential standards in the planting of lettuce.

Two tests will be carried out to see the development of the vegetable, and parameters such as the quality and time of its development will be seen. The first test will be done in the greenhouse where one will plant seeds of silk lettuce. This variety of lettuce takes between 8 to 12 days to give the first shoots, with favorable climatic conditions. One wants to reduce germination to fewer days to be able to have it before possible the product. Since it is isolated and controlled by the greenhouse, it will climatize the environment with the purpose of the correct development of the silk lettuce. It will give adequate watering to the land that must include moisture values between $60 \%$ and $80 \%$ that are desirable for the development of the plant. Likewise, it will provide an adequate temperature with ranges between 18 and 20 degrees Celsius and an ambient humidity necessary for the rapid growth of the plant. The idea is to control any incidence of gases that may affect the development of the vegetable and be able to have it in normal conditions.

The second test, one will take an area of 1.2 meters long by 1.2 meters wide. In this space, one will make planting of lettuce, but it will be exposed to environmental conditions, we will put the necessary measures to isolate and enclose it. It will be in an environment without any care in terms of temperature, soil moisture, humidity, and gases. The idea is to be able to visualize the growth in environmental conditions, and that takes so long to make the germination of the first shoots of lettuce to be able to make a comparison. If indeed, the automated greenhouse generates a better product, in a shorter time and a higher quality. The greenhouse will be careful under favorable conditions that would give us a saving in the use of electric power, greater efficiency in water use, and the economic part. This situation reflects basically the cost of the family basket. It would be an excellent start to recreate this system in each house of our district to generate a better quality of life.

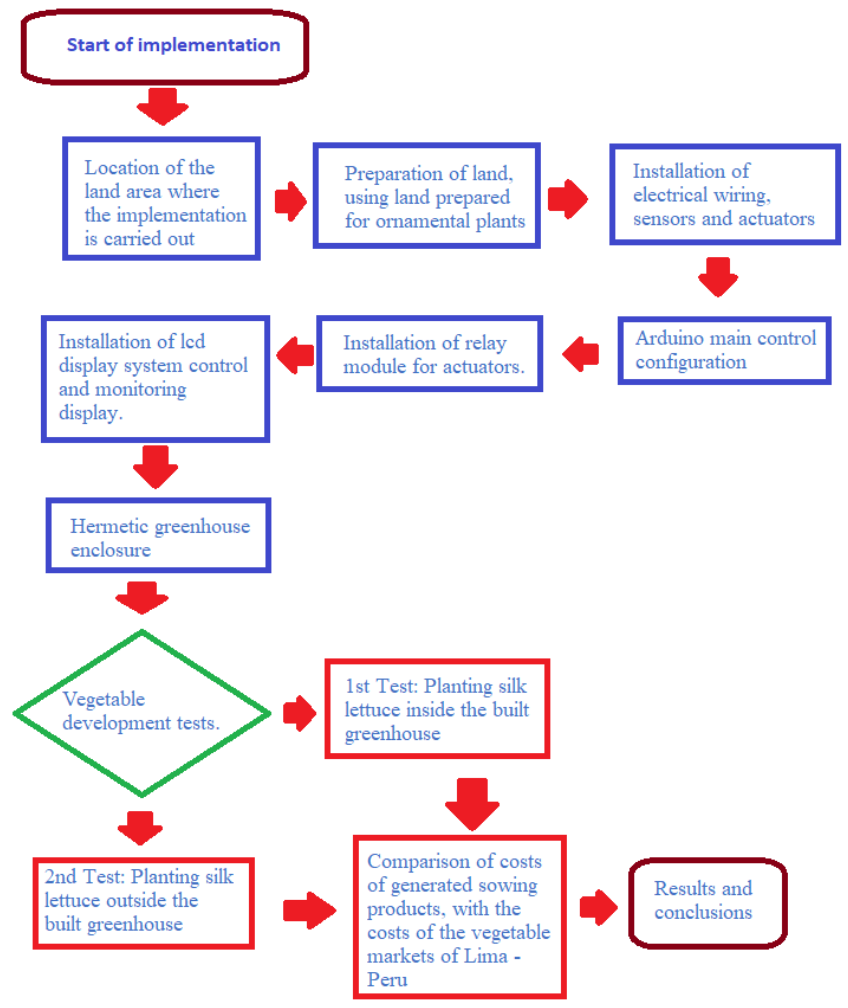

Fig. 1. Flowchart of the Implementation Process and Results. 


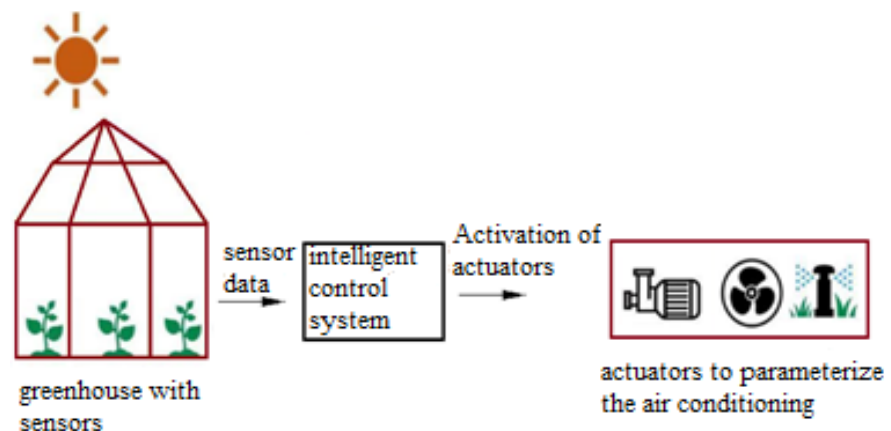

Fig. 2. Automated Implementation Schemes.

\section{B. Climate Variables}

1) Temperature: The temperature is an essential variable in the development of the germination and the growth of the silk lettuce. It must be controlled efficiently to have a healthy crop and above all of better quality. Then, one will manage specific ranges of temperature for the development of our lettuce, and this can be seen in Table I.

2) Humidity: The humidity is an important variable, and the necessary care must be given. Since an excess of humidity in the environment can damage the growth of the plant with different factors, as well as fungi or rot on the leaves. The environment should be humidities between $60 \%$ and $80 \%$ for adequate development of lettuce, as seen in Table II.

3) Soil moisture: The soil moisture similar to the humidity should be between $60 \%$ and $80 \%$. If in case it is less than this amount will delay the growth of the lettuce. Likewise, the irrigation that must be done is a small amount of watering of water to avoid rottenness in the neck of the stem, and in Table III, one can see these values.

4) Carbon dioxide: To control the variable carbon dioxide in our automated greenhouse, one uses an HS-1 that is a portable $\mathrm{CO} 2$ meter with a range of 0 to $2500 \mathrm{ppm}$. The lettuce needs, for its cultivation, the range of $900 \mathrm{ppm}$ to 1600 ppm for the correct photosynthesis. Otherwise, the $1600 \mathrm{ppm}$ barrier will pass the air extraction system that is activated to level the $\mathrm{CO} 2$ levels has been basal.

5) Mineral content: For the development of the research, one uses the horiba laqua meters. They can measure levels of $\mathrm{ph}$, nitrate, potassium, calcium, and more minerals that help the development of the plant. One monitor in real-time to correct any deficiency. In Table IV one can see those values.

6) Light: The variable light in the research of lettuce planting is significant for the development of the crop and its photosynthesis. In the same way, the greenhouse is designed to be able to receive natural light through the transparent cover that is on the roof.

\section{Pests and Diseases}

Every vegetable has pests that affect the development of the crop. Likewise, one is in the district of Villa El Salvador that presents humidity relative to $80 \%$ and conducting soil studies. One finds a pest that directly affects the planting of lettuce and is the warm gray that develops in this type of weather. These worms attacks feeding on the roots or on the shoots that are closest to the ground. To eradicate them one use a mixture of pyrethroid with water and through the water pump and drip irrigation. The insecticide is dispersed reducing the pest and controlling it.

1) Alternaria dauci: It is a disease that occurs in lettuce when it is exposed to high levels of humidity. Fungi that are difficult to detect with the naked eye appear are like dark spots on the leaves. These fungi control them efficiently and reduce high levels of humidity, activates the air extraction system. This situation is in order to pass through a salt filter to internally reduce the humidity of the greenhouse and control the disease.

\section{Programming and Operation}

When talking about the programming and its operation, one addresses to the platform of assembly of the program. In this case, Arduino will be used. First, one needs the necessary libraries; in this case, we will use two essential libraries that are: include "DHT.h" and include <LiquidCrystal_I2C.h>. These libraries allow better control of the temperature and humidity sensor DTH 11 and the liquid crystal i2c libraries. It is to reduce the use of pins and use the $\mathrm{i} 2 \mathrm{c}$ communication protocol, for improved transmission of data in real-time to a screen LCD.

TABLE. I. TEMPerature ${ }^{\circ} \mathrm{C}$ OF THE LetTuce

\begin{tabular}{|l|l|l|l|}
\hline \multirow{2}{*}{$\begin{array}{l}\text { PHASES OF } \\
\text { CULTIVATION }\end{array}$} & \multicolumn{3}{|c|}{} \\
\cline { 2 - 4 } GERMINATION & $1^{\circ} \mathrm{C}-20^{\circ} \mathrm{C}$ & $14^{\circ} \mathrm{C}$ & $28^{\circ} \mathrm{C}$ \\
\hline INCREASE & $\begin{array}{l}16^{\circ} \mathrm{C}-19^{\circ} \mathrm{C}(\text { day) } \\
12^{\circ} \mathrm{C}-16^{\circ} \mathrm{C}(\text { night })\end{array}$ & $11^{\circ} \mathrm{C}$ & $28^{\circ} \mathrm{C}$ \\
\hline FRUIT & $\begin{array}{l}16^{\circ} \mathrm{C}-19^{\circ} \mathrm{C} \text { ( day ) } \\
13^{\circ} \mathrm{C}-16^{\circ} \mathrm{C} \text { (night) }\end{array}$ & $1^{\circ} \mathrm{C}$ & $28^{\circ} \mathrm{C}$ \\
\hline
\end{tabular}

TABLE. II. ENVIRONMENTAL HUMIDITY OF THE LETTUCE

\begin{tabular}{|c|c|c|c|}
\hline \multirow{2}{*}{$\begin{array}{l}\text { PHASES OF } \\
\text { CULTIVATION }\end{array}$} & \multirow[b]{2}{*}{ OPTIMAL } & \multirow[b]{2}{*}{ MINIMUM } & \multirow[b]{2}{*}{ MAXIMUM } \\
\hline & & & \\
\hline GERMINATION & $60 \%-80 \%$ & $50 \%$ & $95 \%$ \\
\hline INCREASE & $60 \%-80 \%$ & $45 \%$ & $85 \%$ \\
\hline FRUIT & $60 \%-80 \%$ & $45 \%$ & $85 \%$ \\
\hline
\end{tabular}

TABLE. III. HUMIDITY OF EARTH H\%

\begin{tabular}{|l|l|l|l|}
\hline PHASES OF & \multicolumn{3}{|c|}{} \\
\cline { 2 - 4 } CULTIVATION & OPTIMAL & MINIMUM & MAXIMUM \\
\hline GERMINATION & $\mathbf{6 0 \% - 8 0 \%}$ & $\mathbf{4 0 \%}$ & $\mathbf{9 8 \%}$ \\
\hline INCREASE & $\mathbf{6 0 \% - 8 0 \%}$ & $\mathbf{4 0 \%}$ & $\mathbf{8 5 \%}$ \\
\hline
\end{tabular}

TABLE. IV. GROUND Minerals

\begin{tabular}{|l|l|l|}
\hline \multirow{2}{*}{$\begin{array}{l}\text { MINERALS FOR } \\
\text { CROP }\end{array}$} & \multicolumn{2}{|c|}{} \\
\cline { 2 - 3 } & MINIMUM & MAXIMUM \\
\hline PH & $5.8 \mathrm{ph}$ & $7.2 \mathrm{ph}$ \\
\hline CALCIUM & $15 \mathrm{gr}$ & $17 \mathrm{gr}$ \\
\hline $\begin{array}{l}\text { POTASSIUM } \\
\text { NITRATE }\end{array}$ & $2 \mathrm{~kg}$ & $3 \mathrm{~kg}$ \\
\hline
\end{tabular}


The DTH 11 sensor has the functionality to read the temperature and humidity variables in real-time, and the control flow for temperature can be seen in Fig. 3.

The MQ2 sensor has the functionality of being able to read the variable of propane gas in a basal state that is around $50 \mathrm{G}$ to $110 \mathrm{G}$. If it exceeds the basic parameters that one has programmed in the $180 \mathrm{G}$ command lines, which may influence or affect the greenhouse ecosystem, the air extraction system will be activated in order to stabilize the automated greenhouse as seen in Fig. 4.

Earth moisture sensor, like the other sensors, will record the soil moisture of our greenhouse, to see if the proportion of humidity that should comprise values higher than $70 \%$. Otherwise will activate the water pump to generate drip irrigation and the control flow can be seen in Fig. 5. In Fig. 6, one can see the general diagram block.

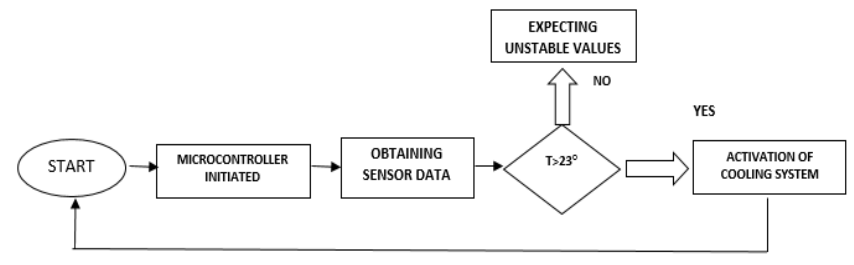

Fig. 3. Temperature Control Flow.

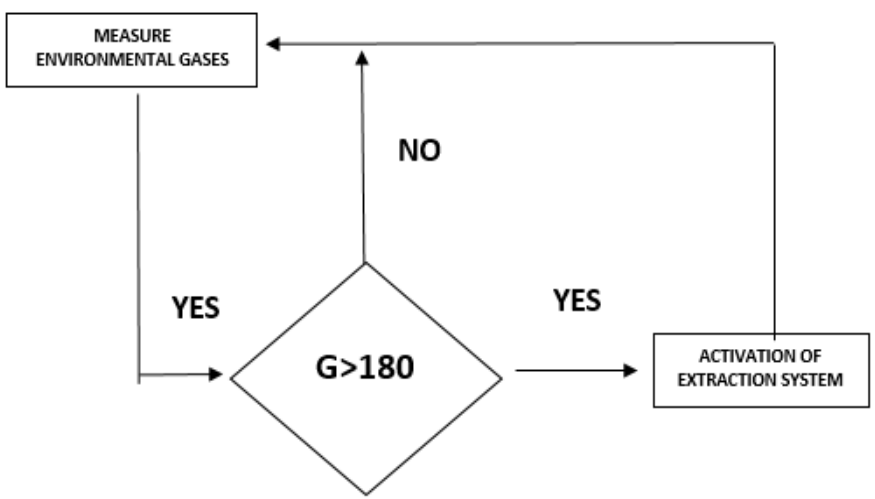

Fig. 4. Ambient Gas Control Flow.

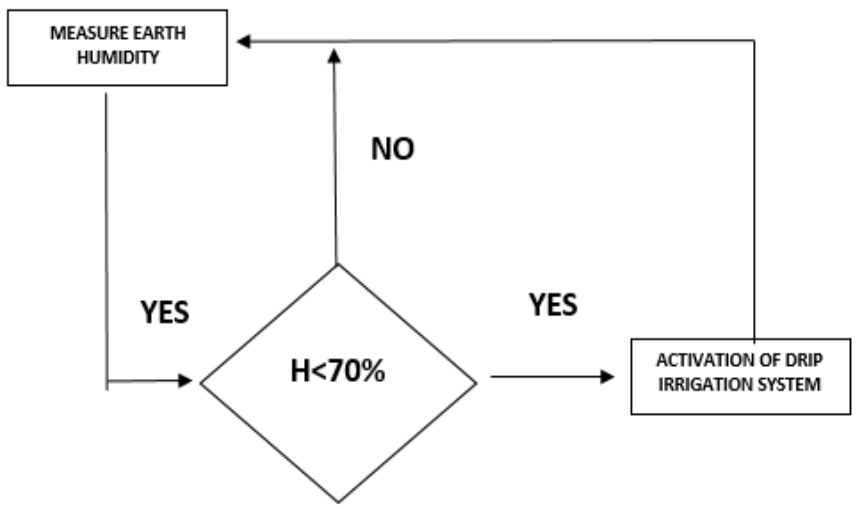

Fig. 5. Ground Moisture Control Flow.

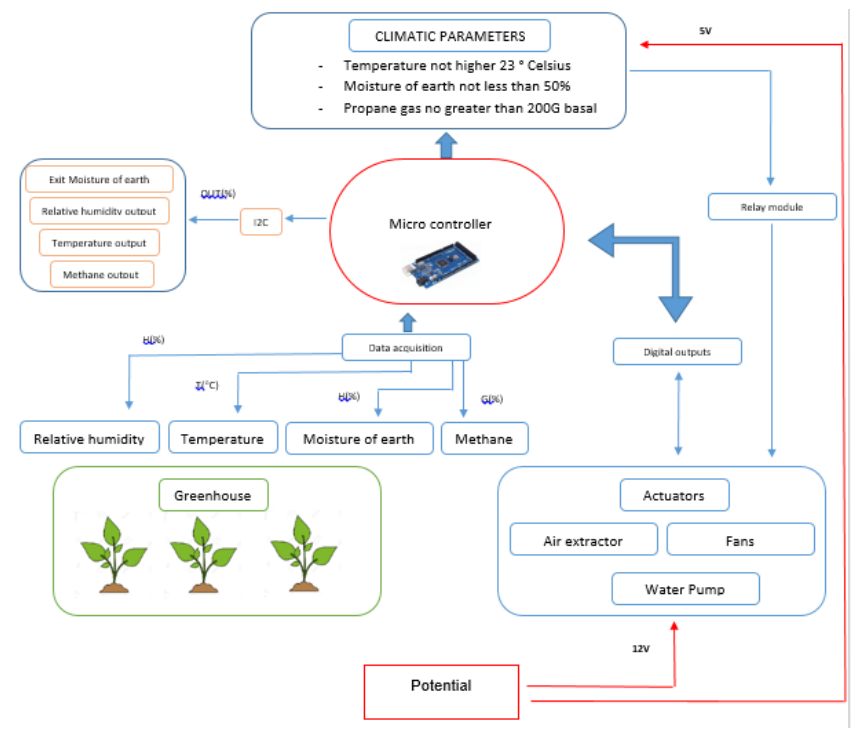

Fig. 6. Automated Greenhouse Control Schemes.

\section{DISCUSSION}

Based on the findings, one can say that the cost of the family basket can be reduced by implementing low-cost automated greenhouses in the Villa El Salvador District. Likewise, the objectives of sustainable development are met. Poverty, improve health and well-being in terms of the quality of life of the population.

As for the results obtained, one finds itself in total disagreement with the research "Organic Orchard Gardens in the San José neighborhood" [8] since, in the period of one year, 744 dollars was spent to obtain 372 kilos of lettuce for 87 families. This situation would be 4.27 kilos for a cost of 8.55 dollars per family, which unlike was spent 5 dollars on the planting of the vegetable and one has 45 lettuces with a projection to increase. Likewise, the process used to farming is mechanical, both irrigation and ventilation, which brings a slowdown in the growth of the plants and not an automated process like ours.

Our result correlates with the construction of a Start-up focused on saving money in the purchase of products from the family basket [7]. Since one is going in only one direction, which is to reduce the cost of the family basket, it would be integrated in an appropriate way to plant the fast-growing vegetables. The start-up would be used to acquire the missing products to have an adequate nutritional supplement. This situation would have significant savings in terms of the economic. The improvement of the family basket would also be improved with the help of Peruvian state policies with social programs, giving this problem a plus [10].

One agrees with the results given the research of greenhouses in high Andean areas. Since our study gives us the economic savings values are very similar in our case 8 dollars and the greenhouses high Andean areas 10 dollars. All these significant savings is to improve the family basket and take advantage of productivity [12]. 


\section{RESULTS}

With a period of 20 days, one obtained 40 shoots of lettuce with a projection to an increase in the passing of days. Surveys were conducted in the Santa Rosa market and the Santa Anita Producers market to know the real cost of the lettuce. The idea is to make the respective analysis for the economic savings in its research, and one can see the results in Table $\mathrm{V}$.

TABLE. V. ANALYSIS AND COMPARATIVE RESUlts OF PRICES OF LETTUCE IN THE MARKETS OF THE DISTRICT OF VILLA EL SALVADOR

\begin{tabular}{|l|l|l|l|}
\hline Criteria & $\begin{array}{l}\text { Automated } \\
\text { Greenhouse }\end{array}$ & $\begin{array}{l}\text { Producers } \\
\text { Market of } \\
\text { Santa Anita }\end{array}$ & $\begin{array}{l}\text { Santa Rosa } \\
\text { Market of Villa } \\
\text { el Salvador }\end{array}$ \\
\hline $\begin{array}{l}\text { Surveys to Sellers } \\
\text { of vegetables }\end{array}$ & 1 & 7 & 6 \\
\hline Price lettuce unit & $\$ / .0 .20$ & $\$ / .0 .30$ & $\$ / .0 .40$ \\
\hline $\begin{array}{l}\text { Savings per unit of } \\
\text { lettuce }\end{array}$ & $\begin{array}{l}\$ / .0 .10-\$ / . \\
\mathbf{0 . 2 0}\end{array}$ & $\$ / .0 .00$ & $\$ / .0 .00$ \\
\hline
\end{tabular}

As can be seen in the results, there is a significant saving when comparing the two most important markets in the districts of Lima and Villa el Salvador, in terms of the cost of lettuce. While in the greenhouse the cost per unit of lettuce is $\$ 0.20$, in the market the price is higher. If the lettuce were sold at the market price that is $\$ 0.40$ each, we would obtain a saving of $\$ 0.20$ per unit multiplied by the 40 lettuces obtained would be $\$ 8.00$.

One also has significant savings in the implementation of the automated greenhouse, because we use recyclable materials to reduce the costs in the assembly of the structure. One also built and implemented the entire project, which was significant in the total completion greenhouse.

\section{CONCLUSION}

The research carried out provides an intelligent automated greenhouse system. The controls different environmental parameters, improving the productivity and increase of the vegetables (as seen in the results). Consequently, a reduction of the cost of the family basket in the District of Villa el Savior.

Another essential objective is the reuse of recycling in the process of implementation, to lower the costs of assembly of the automated greenhouse. Likewise, we focus on the aim of sustainable development, which is responsible for production and consumption to take care of the environment.
TABLE. VI. GREENHOUSE IMPLEMENTATION COSTS

\begin{tabular}{|l|l|}
\hline AUTOMATED GREENHOUSE & PRICE \\
\hline $\begin{array}{l}\text { HARDWARE ELECTRONIC (arduino, sensors, actuators, } \\
\text { chargers, hs1, horiba laqua) }\end{array}$ & $\$ / .65$ \\
\hline $\begin{array}{l}\text { HARDWARE MATERIALS (talk structure, cover, belts, } \\
\text { cables) }\end{array}$ & $\$ / .30$ \\
\hline SOFTWARE & $\$ / .15$ \\
\hline PEOPLEWARE WORK & $\$ / .30$ \\
\hline
\end{tabular}

Regarding the actions to be taken, the idea is to present this research to the people of the District of Villa El Salvador. With this situation, they get involved with the technology. Parallel to this, take an environmental awareness and see other options to improve the quality of community life, as seen in Table VI.

\section{REFERENCES}

[1] Felipe A. Yevilao Cuevas, "Automated Temperature Control, Humidity, Irrigation by Misting for lettuce scale cultivation", 2018, pp 28-30.

[2] Hernan Alarcon .L, Geyni Arias .V, Javier Diaz and David Soto .V, "Design of a control and automation system for temperature, ground humidity and relative humidity to optimize crop yield under cover in CORHUILA" 2017, pp 49-51.

[3] Gurban, Eugen Horatiu; Andreescu, Gheorghe-Daniel "Environmental Engineering \& Management Journal” (2018): vol 17: pp. 399-416.

[4] Nicolosi, Volpe, y Messineo "An innovative adaptive control system to regulate microclimatic conditions in a greenhouse.” 2017, pp 722.

[5] INEI "Idicators of price of the Economy" 2018, pp 63-71.

[6] INEI "Yearbook of environmental statistics" 2018 pp 63-66.

[7] Vandana Rangrao .H "An automated climate control system for greenhouse use deep learning for tomato crops" 2018, pp 94-96.

[8] Carlos Eduardo Pabón .G "Construction of a Startup focused on the Money Saving in the Acquisition of Products of the Family Basket" 2019, pp 20-39.

[9] Fany Asqui Yuquilema"Feasibility study for the implementation of family organic gardens in the San neighborhood José Del Vínculo, parish of Sangolquí, Rumiñahui canton" 2018, pp 36-43.

[10] Office of the Comptroller General of the Republic of Peru "report of the control services of the social programs in charge of the state" 2015, pp. 33-37.

[11] Chirinos Centes Adolfo, Herrera Lagos Renzo“ Implementación de un invernadero a escala para la creacion de una empresa productora de lechuga hidroponica en Lima Metropolitana"2016, pp 16-35.

[12] Zambria Pacheco Pedro .G "Invernaderos sostenibles para la producción de hortalizas en zonas alto andinas del Cusco t” 2019, pp 97-104. 